\title{
The Development of Interactive Learning Media Based on PBL Learning Models on Theme 9 Sub-theme 3 for Fifth Grade Elementary ASchool
}

\author{
Wulan Endah Citra Suwito \\ Program Studi Pendidikan Guru Sekolah Dasar, Universitas PGRI Semarang, Semarang, Indonesia \\ e-mail: citrawulan452@gmail.com
}

Fine Reffiane

Program Studi Pendidikan Guru Sekolah Dasar, Universitas PGRI Semarang, Semarang, Indonesia e-mail: reffianefine@gmail.com

Ryky Mandar Sary

Program Studi Pendidikan Guru Sekolah Dasar, Universitas PGRI Semarang, Semarang, Indonesia e-mail: rykymandarsary@gmail.com

\section{A R T I C L E I N F O \\ Article history: \\ 25 December 2020 \\ Received in revised form \\ 01 January 2021 \\ Accepted 25 January 2021 \\ Available online 03 Pebruari 2021 \\ Kata Kunci: \\ Media Interaktif, $P B L$ \\ Pengembangan, SD \\ Keywords: \\ Interactive Media, PBL, \\ Development, $S D$}

\begin{abstract}
A B S T R A K
Penggunaan media pembelajaran di sekolah yang kurang optimal mengakibatkan aktivitas siswa menjadi kurang aktif mengikuti pembelajaran, sehingga diperlukan media yang dapat memotivasi siswa. Tujuan penelitian ini adalah untuk menganalisis produk berupa media pembelajaran interaktif berbasis model pembelajaran PBL yang valid dan layak digunakan pada tema 9 subtema 3 untuk kelas V SD. Jenis penelitian ini adalah penelitian pengembangan dengan menggunakan model ADDIE. Subjek penelitian ini adalah validitas media pembelajaran interaktif berbasis model pembelajaran PBL. Metode pengumpulan data yang digunakan adalah dengan memberikan instrumen non-tes kepada ahli media dan materi, serta guru dan siswa di tiga SD. Instrumen yang digunakan pada penelitian ini berupa angket. Metode analisis data penelitian pengembangan ini dilakukan dengan teknik analisis deskriptif kualitatif dan kuantitatif. Hasil penelitian ini menunjukkan bahwa diperoleh prensentase sebesar $84,89 \%$ oleh ahli media dan $82,67 \%$ oleh ahli materi, sedangkan tanggapan guru dari ketiga SD menunjukkan presentase sebesar $96 \%, 82 \%, 96 \%$ dan tanggapan siswa dari ketiga SD menunjukkan presentase sebesar $97,39 \%, 96,09 \%, 97,5 \%$. Sehingga dapat disimpulkan bahwa media pembelajaran interaktif sangat valid dan sangat layak untuk digunakan.
\end{abstract}

\begin{abstract}
A B S T R A C T
The background that drives this research is that teachers are less than optimal in using instructional media in the learning process. Lack of use of learning media results in less active and passive student activities, so that students' understanding of the material is still lacking. This research aims to produce a product in the form of interactive learning media based on the PBL learning model that is valid and suitable for use in theme 9 sub-themes 3 for grade V SD. This type of research and development uses the ADDIE model. The data collection instrument in this study used a questionnaire. The method of data analysis in this research and development was carried out by using qualitative descriptive analysis techniques and quantitative descriptive analysis. Media experts and material experts validated that interactive learning media products developed were validated, showing the percentage of $84.89 \%$ and $82.67 \%$ were categorized as "very valid and very suitable for use". Meanwhile, the teacher responses from the three primary schools showed a percentage of $96 \%, 82 \%, 96 \%$ were categorized as "very valid and very suitable for use", and the responses of students from the three primary schools showed a percentage of $97.39 \%, 96.09 \%, 97.5 \%$ in the category "very valid and very worthy of use". So it can be concluded that interactive learning media is very valid and very feasible to use.
\end{abstract}

\section{Introduction}

Education has a very important role and cannot be separated from today's life, the government through the minister of education is developing the 2013 curriculum by emphasizing thematic learning that is applied in schools starting in the 2013/2014 school year (Amelia \& Saputra, 2017; Kurniasari, 2017; Purwanti, 2017). Thematic learning is given to bring together curriculum content into intact units or units and make learning more meaningful and easy for students to understand. Thematic learning can be effective and efficient by using various learning media in the classroom as a learning resource. 
Based on the results of observations made on three elementary schools, namely SD Negeri Sudo on September 27, 2019, SD Negeri 01 Kaliombo on September 28, 2019, and SD Negeri 02 Kaliombo on October 4, 2019 in Rembang Regency, it was found that the results of the interview showed that the teacher had a problem. The same regarding the learning resources used, both thematic books and companion books. In learning activities, teachers do not apply material with learning media in the classroom environment. Less optimal use of learning media results in student activities becoming less active and passive so that students' understanding of the material is still lacking (Citrasmi et al., 2016; Maufur \& Lisnawati, 2017; Ulfah \& Soenarto, 2017).

Seeing that there are supporting facilities from each school such as LCD, speakers, and the internet, efforts can be made to overcome the above problems, using interactive learning media. In addition, teachers are also skilled in operating computers. It is possible if interactive learning media are used as an alternative to optimizing the learning process, especially in thematic learning (Maharani \& Kartini, 2019; Sari \& Suswanto, 2017; Sofyan et al., 2018).

According to Prayogo (Riani et al., 2015; Setyaningsih et al., 2020; Yuniarni et al., 2020) Interactive learning media is a medium that is combined from various elements such as text, photos, sound, animation, and video, which is equipped with a controller that the user can operate to convey the contents of teaching material which includes books, tape recorders, cassettes, video cameras., video recorders, films, slides, photos, pictures, graphics, television, and computers. This interactive media can be a learning medium that involves children's cognitive, affective, and psychomotor sides. Interactive learning media can make the learning process more interesting, more interactive, the amount of time can be reduced, the quality of student learning can be improved, the teaching and learning process can be done anywhere and anytime, and student learning attitudes can be improved. Interactive learning media can help students solve problems with critical thinking skills so that factors that can stimulate these abilities are needed, such as selecting learning models.

In this research and development, the researcher chose the PBL learning model as a complement in using interactive learning media. According to (Istiandaru et al., 2015; Juliawan et al., 2017; Wajdi, 2017), the PBL learning model is a learning approach that has the advantage of using real-world problems as a context for students to learn about critical thinking and problem-solving skills and to gain knowledge and concepts that are the essence of subject matter, so that the learning obtained by students is more meaningful. The steps for the PBL learning model are as follows: (1) student orientation to problems, (2) organizing students to learn, (3) guiding individual and group investigations, (4) developing and presenting work, (5) analyzing and evaluating the problem-solving process (Han \& Rosli, 2016; Ratnawati et al., 2020; Sumarni et al., 2016).

Several relevant studies support this research. The first research conducted by (Akbar, 2019), who get the results based on material expert validation, media expert validation, and interactive multimedia trial results on human respiratory system material, is declared very feasible and can be implemented in learning. Both studies were carried out by (Sutarno \& Mukhidin, 2013), who get the results that the interactive multimedia-based learning model with the principles of learning technology can make students' interest in learning increase process feels interesting and fun. The three studies conducted by (Rohati et al., 2018), who get the result that the developed mathematics comic learning media based on problem-based learning (PBL) is included in the good media quality category.

The research carried out has a research objective, namely to analyze the development of a study program in interactive learning media based on PBL learning models on theme 9 sub-themes 3 for fifth-grade elementary schools.

\section{Method}

This research is a research and development (research and development). Research and development is a research method used to produce certain products and test the effectiveness of these products. This type of research and development uses the ADDIE model. The ADDIE model consists of five stages of activity: analysis, design, development, implementation, and evaluation.

This research is interactive learning media based on the PBL learning model on theme 9 sub-theme 3 for fifth-grade elementary schools. This research was conducted in the fifth grade of elementary schools, namely SD Negeri Sudo, SD Negeri 01 Kaliombo, and SD Negeri 02 Kaliombo. This research was conducted in June 2020.

The data collection method used was by giving questionnaires to media experts, material experts, teachers, and students in three schools. The data collection instruments used by researchers in research and development were in the form of a questionnaire consisting of a media expert validation questionnaire, a material expert validation questionnaire, a teacher response questionnaire, and a student response questionnaire. 
The data obtained based on a questionnaire given to media experts, material experts, teachers, and students in three schools were analyzed by calculating the average score obtained. The data analysis used was quantitative descriptive analysis to calculate the percentage of validation results and qualitative descriptive analysis to analyze the responses of teachers and students.

\section{Result and Discussion}

The product developed in this study is interactive learning media with the theme of 9 sub-themes 3 for the fifth-grade elementary school. This research and development use the stages of the ADDIE development model. This model consists of five stages: analysis, design, development, implementation, and evaluation.

The first step in the analysis is to identify the problem. This analysis was carried out directly with fifthgrade students and teachers as a basis for determining the problems faced. Based on the results of this analysis, the same problems were found regarding the learning resources used by the teacher. Therefore, it is necessary to develop interactive learning media as a solution.

In the second stage, the researcher designed the developed media. Interactive learning media is designed using computer software. It is in line with (Kirna, 2012; Sutarno \& Mukhidin, 2013; Yuniarni et al., 2020). Interactive learning media is computer-based learning media consisting of text, graphics, audio, and video created, packaged, presented, and used interactively through computers. The design of interactive learning media includes the stages of determining the material, making media designs, and compiling quizzes and answers.

The third stage is development. At this stage, it begins with making interactive learning media products. Interactive learning media products on theme 9 sub-theme 3 for fifth-grade elementary school are packaged on a CD. It is following Kustandi's opinion (Bahtiar, 2019; Fais et al., 2019; Laily et al., 2019) that learning media are used to convey material in the form of books, tape recorders, cassettes, video cameras, video recorders, films, slides, photos, pictures, graphics, television, and computers.

Furthermore, the researcher corrected the interactive learning media design results that had been compiled before being validated. If it was appropriate, then it was ready to be validated. This validation was carried out by media experts and material experts consisting of three experts. The graph of the questionnaire assessment of media experts and material experts can be seen in Figure 1.
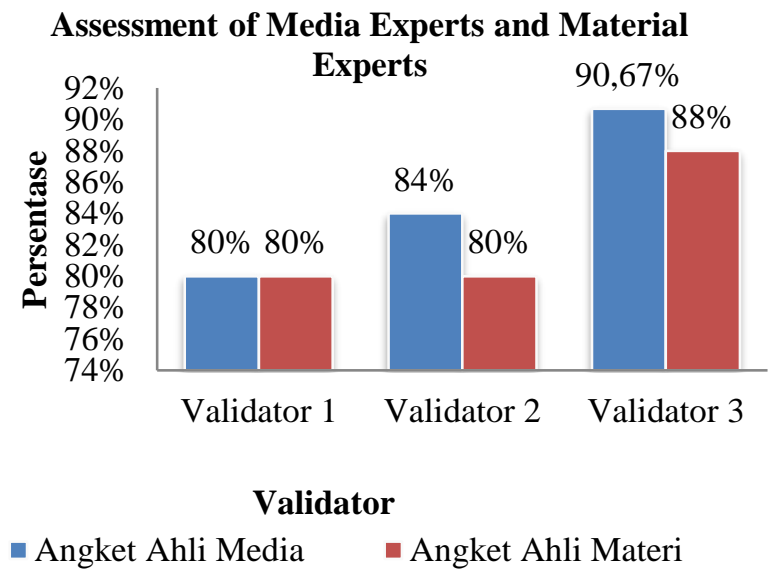

Figure 1. Graph of Media Expert and Material Expert Assessment

Based on Figure 1 that the average assessment of the media expert questionnaire on interactive learning media from the three experts reached a percentage of $84.89 \%$, and the average assessment of the material expert questionnaire on interactive learning media from the three experts reached a percentage of $82.67 \%$, it can be concluded that the media interactive learning is very valid and very feasible to use in learning.

The fourth stage is implementation. At this stage, the product will be thoroughly tested in fifth grade SD Negeri Sudo, SD Negeri 01 Kaliombo, and SD Negeri 02 Kaliombo. At this stage, a questionnaire is distributed to find out the feasibility of the product.

The fifth stage is evaluation. At the trial stage, a product assessment was obtained, manifested in teacher response questionnaires and student response questionnaires. The data from the questionnaire were then described into quantitative data to be transformed into qualitative data. The teacher response questionnaire graph can be seen in Figure 2. 
Teacher Response Assessment Results

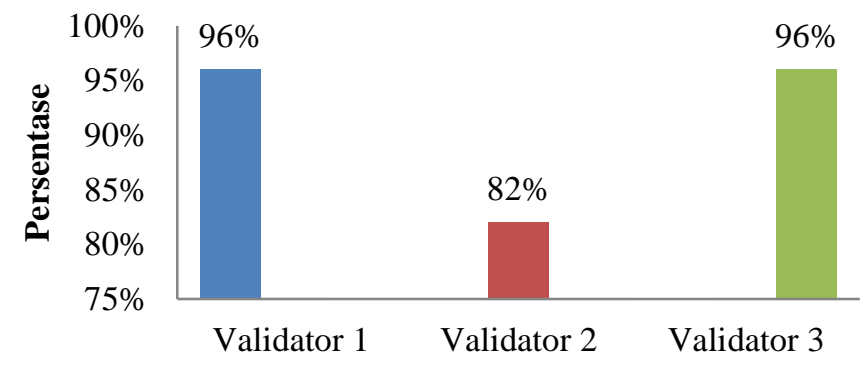

Validator

घalidator $1 \quad$ Validator $2 \quad \square$ Validator 3

Figure 2. Teacher Response Graph

Based on Figure 2, the average teacher response questionnaire assessment reaches a percentage of $82.67 \%$. It can be concluded that interactive learning media is very valid and very suitable for learning. Following these average results, the teacher said that interactive learning media was very interesting, practical, and easy to use in explaining the material to increase students' activeness and understanding of the learning material. It is in line with research conducted by (Kirna, 2012; Sutarno \& Mukhidin, 2013; Yuniarni et al., 2020) that the application of interactive media in the learning process is very good because it is following the world of today's children who are more interested in learning materials in moving and colorful images, so this media is good for use in explaining and understanding the material.

Meanwhile, the student response questionnaire was given after students observed and used interactive learning media. It is following the opinion expressed by (Firdaus et al., 2020; Heru \& Yuliani, 2020; Yuniarni et al., 2020) that learning is a process of changing behavior to achieve various knowledge, skills, and attitudes through a series of learning activities, for example by reading, observing, and listening. The graph of the student response questionnaire can be seen in Figure 3.

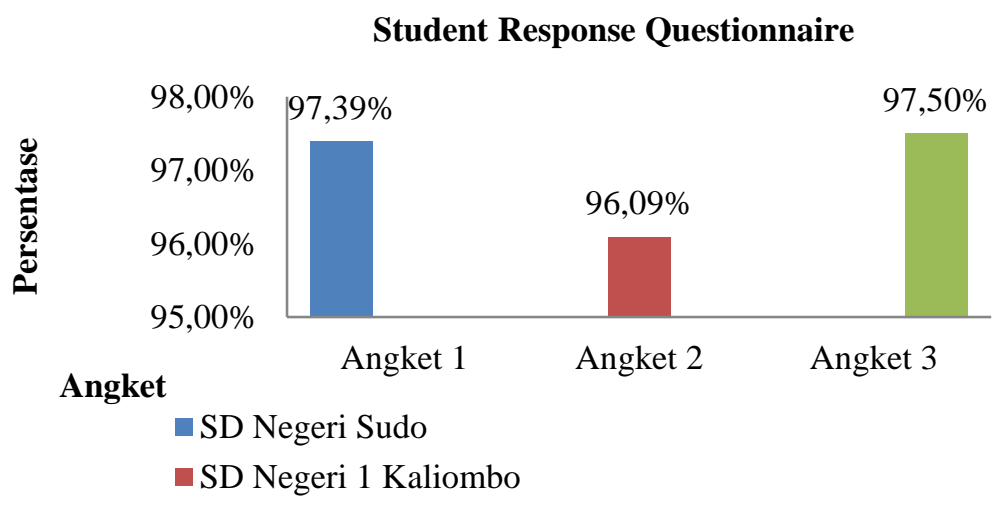

Figure 3. Student Response Graph

Based on Figure 3, the average student response questionnaire assessment reaches a percentage of $96.99 \%$. It can be concluded that interactive learning media is very valid and feasible to use. Students consider that interactive learning media is very attractive and practical so that students like it and find it easy to understand the material. It is following the research conducted by (Ashfahany et al., 2017; Kirna, 2012; Putra \& Sujarwanto, 2017) that interactive learning media can help process learning activities and facilitate the absorption of material besides that this media is said to be interesting, funny, and fun.

The results of the development of interactive learning media are, first, the start page that appears when the program is started, this page contains the kids background, the words "Interactive Learning Media with the theme 9 Human and Objects in their Environment" and several menu options that are equipped with buttons to run such as instructions, start, profile and exit. Second, the instruction page contains instructions for the use of each button on interactive learning media. Third, the menu page has music and three menu options such as basic 
competencies, materials, quizzes, and exit. Fourth, the basic competency page displays basic competencies on theme 9, sub-theme 3, home button, and exit button. Fifth, the material page displays 6 material choices on the theme of 9 sub-themes 3, the home button, and the exit button. The material is displayed in the form of a short video. Sixth, the quiz page displays instructions for use, questions, and quiz results.

The use of interactive learning media can encourage student activity and motivation. It is in line with the research results (Kirna, 2012; Sutarno \& Mukhidin, 2013; Yuniarni et al., 2020) that interactive learning media gets a positive response it is said that students like this media. In addition, this interactive learning media was developed as an alternative source of student learning used independently and in groups. It is in line with the opinion expressed by (Ashfahany et al., 2017; Kirna, 2012; Putra \& Sujarwanto, 2017) that interactive multimedia has the advantage that it can be used for independent and classical learning so that students with various levels of ability can use it without feeling difficult because it is equipped with instructions for use.

In this research and development, the researcher chose the PBL learning model as a complement in using interactive learning media. According to (Istiandaru et al., 2015; Juliawan et al., 2017; Wajdi, 2017), the PBL learning model is a learning approach that has the advantage of using real-world problems as a context for students to learn about critical thinking and problem-solving skills and to gain knowledge and concepts that are the essence of subject matter, so that the learning obtained by students is more meaningful. The steps for the PBL learning model are as follows: (1) student orientation to problems, (2) organizing students to learn, (3) guiding individual and group investigations, (4) developing and presenting work, (5) analyzing and evaluating the problem-solving process (Han \& Rosli, 2016; Ratnawati et al., 2020; Sumarni et al., 2016).

Several relevant studies support this research. The first research conducted by (Akbar, 2019), who get the results based on material expert validation, media expert validation, and interactive multimedia trial results on human respiratory system material, is declared very feasible and can be implemented in learning. Both studies were carried out by (Sutarno \& Mukhidin, 2013), who get the results that the interactive multimedia-based learning model with the principles of learning technology can make students' interest in learning increase process feels interesting and fun. The three studies conducted by (Rohati et al., 2018) get the result that the developed mathematics comic learning media based on problem-based learning (PBL) is included in the good media quality category.

\section{Conclusion}

Based on the results of research and discussion, it can be concluded that interactive learning media is very valid and very suitable for use in learning. Interactive learning media products on theme 9 sub-theme 3 for fifth-grade elementary school are packaged on a CD. Interactive learning media is also equipped with animation, video, sound effects, and instructions to make it easier to use. The learning created is not boring and can attract students' attention. The research results that have been carried out in three elementary schools, namely SD Negeri Sudo, SD Negeri 01 Kaliombo, and SD Negeri 02 Kaliombo, the researcher suggests that schools, especially teachers, can use interactive learning media as a learning resource.

\section{References}

Akbar. (2019). Implementasi Model Pembelajaran Berbasis Masalah untuk Meningkatkan Hasil Belajar Siswa pada Mata Pelajaran PKn di SMA Negeri 1 Batukliang Utara. Jurnal Kependidikan: Jurnal Hasil Penelitian Dan Kajian Kepustakaan Di Bidang Pendidikan, Pengajaran Dan Pembelajaran, 5(1), 1-7. https://doi.org/https://doi.org/10.33394/jk.v5i1.1386

Amelia, D. J., \& Saputra, S. Y. (2017). Analisis Kelayakan Buku Siswa Kelas IV Tema Makhluk Hidup Kurikulum 2013. Pedagogia: Jurnal Pendidikan, 6(1), 98-109. https://doi.org/10.21070/pedagogia.v6i1.617

Ashfahany, F. A., Adi, S., \& Hariyanto, E. (2017). Bahan Ajar Mata Pelajaran Pendidikan Jasmani Olahraga dan Kesehatan Dalam Bentuk Multimedia Interaktif Untuk Siswa Kelas VII. Jurnal Pendidikan: Teori, Penelitian, Dan Pengembangan, 2(2), 261-267. https://doi.org/10.17977/jp.v2i2.8540

Bahtiar, R. S. (2019). Efektivitas Penggunaan Media Papan Waktu Pada Pembelajaran Penghitungan Waktu Bagi Siswa Kelas III Sekolah Dasar. Jurnal Bidang Pendidikan Dasar, 3(1), 14-23. https://doi.org/10.21067/jbpd.v3i1.2857

Citrasmi, N. W., Wirya, N., \& Tegeh, I. M. (2016). Pengaruh Model Pembelajaran Scramble Berbantuan Media Gambar Terhadap Hasil Belajar Ipa Di SD. Jurnal Mimbar PGSD Undiksha, 4(2). https://doi.org/10.23887/jjpgsd.v4i2.8425 
Fais, M. Z., Listyarini, I., \& Tsalatsa, A. N. (2019). Pengembangan Media Papin dan Koja (Papan Pintar dan Kotak Ajaib) Sebagai Media Pembelajaran Matematika. Jurnal Penelitian Dan Pengembangan Pendidikan, 3(1), 26-30. https://doi.org/10.23887/jppp.v3i1.17097

Firdaus, F. Z., Suryanti, S., \& Azizah, U. (2020). Pengembangan Multimedia Interaktif Berbasis Pendekatan SETS Untuk Meningkatkan Kemampuan Berpikir Kritis Siswa Sekolah Dasar. Jurnal Basicedu, 4(3), 681-689. https://doi.org/10.31004/basicedu.v4i3.417

Han, S., \& Rosli, R. (2016). The Effect of Science, Technology, Engineering and Mathematics ( STEM ) Project Based Learning ( PBL ) on Students' Achievement in Four Mathematics Topics. Journal of Turkish Science Education, 13, 3-29. https://doi.org/10.12973/tused.10168a

Heru, H., \& Yuliani, R. E. (2020). Pelatihan Pengembangan Bahan Ajar Multimedia Pembelajaran Interaktif Berbasis Pendekatan Saintifik Menggunakan Metode Blended Learning bagi Guru SMP/MTs Muhammadiyah Palembang. Jurnal Pengabdian Pada Masyarakat, 5(1), $35-44$. https://doi.org/10.30653/002.202051.279

Istiandaru, A., Istihapsari, V., Wardono, \& Mulyono. (2015). Problem Based Learning (PBL) dengan Pendekatan Realistik-Saintifik dan Asesmen PISA untuk Meningkatkan Kemampuan Literasi Matematika. Edumatica, 5(1), 1-11. https://doi.org/10.22437/edumatica.v5i01.2670

Juliawan, G. A., Mahadewi, L. P. P., \& Rati, W. R. (2017). Pengaruh Model Problem Based Learning (PBL) Terhadap Kemampuan Pemecahan Masalah Matematika. Mimbar PGSD, 5(2), 1-10. https://doi.org/10.23887/jjpgsd.v5i2.10881

Kirna, I. (2012). Pemahaman Konseptual Pebelajar Kimia Pemula Dalam Pembelajaran Berbantuan Multimedia Interaktif. Jurnal Ilmu Pendidikan, 18(1), 88-97. https://doi.org/10.17977/jip.v18i1.3387

Kurniasari, F. (2017). Implementasi Pendekatan Saintifik Pada Penugasan Aktivitas Di Buku Teks Bahasa Indonesia Kelas VII SMP Berdasarkan Kurikulum 2013. Jurnal Pendidikan Edutama, 4(1), 9-26. https://doi.org/10.30734/jpe.v4i1.44

Laily, A., Jalal, F., \& Karnadi, K. (2019). Peningkatan Kemampuan Konsep Matematika Awal Anak Usia 4-5 Tahun melalui Media Papan Semat. Jurnal Obsesi : Jurnal Pendidikan Anak Usia Dini, 3(2), 396-403. https://doi.org/10.31004/obsesi.v3i2.214

Maharani, N., \& Kartini, K. S. (2019). Penggunaan google classroom sebagai pengembangan kelas virtual dalam keterampilan pemecahan masalah topik kinematika pada mahasiswa jurusan sistem komputer. PENDIPA Journal of Science Education, 3(3), 167-173. https://doi.org/10.33369/pendipa.3.3.167-173

Maufur, S., \& Lisnawati, S. (2017). Pengaruh Penggunaan Media Gambar Berseri Terhadap Keterampilan Berbicara Bahasa Indonesia Siswa Kelas III MI Al-Washliyah Perbutulan Kabupaten Cirebon. Al Ibtida: Jurnal Pendidikan Guru MI, 4(2), 189. https://doi.org/10.24235/al.ibtida.snj.v4i2.1888

Purwanti, K. L. (2017). Penerapan Literasi Lintas Kurikulum Matematika Dalam Pembelajaran Kelas Tinggi Di MIT Nurul Islam Ngaliyan Semarang Tahun 2016. Phenomenon : Jurnal Pendidikan MIPA, 7(1), 79. https://doi.org/10.21580/phen.2017.7.1.1497

Putra, I. A., \& Sujarwanto, E. (2017). Analisis Keterampilan Proses Sains Peserta Didik Melalui Bahan Ajar Multimedia Interaktif Alat Ukur dan Pengukuran dengan Pendekatan Behavioristik. Momentum: Physics Education Journal, 1(2), 91. https://doi.org/10.21067/mpej.v1i2.2013

Ratnawati, D., Handayani, I., \& Hadi, W. (2020). Pengaruh Model Pembelajaran Pbl Berbantu Question Card Terhadap Kemampuan Berpikir Kritis Matematis Siswa SMP. Edumatica: Jurnal Pendidikan Matematika, 10(01), 44-51. https://doi.org/10.22437/edumatica.v10i01.7683

Riani, S., Hindun, I., \& Krisno Budiyanto, M. A. (2015). Pengembangan Media Pembelajaran Berbasis Multimedia Interaktif Untuk Meningkatkan Pemahaman Materi Bioteknologi Modern Siswa Kelas Xii Sma. Jurnal Pendidikan Biologi Indonesia, 1(1), 9-16. https://doi.org/10.22219/jpbi.v1i1.2298

Rohati, Winarni, S., \& Hidayat, R. (2018). Pengembangan Media Pembelajaran Komik Matematika Berbasis Problem Based Learning dengan Manga Studio V05 dan Geogebra. Edumatica, 08(02), 81-91. https://doi.org/10.22437/edumatica.v8i2.5486

Sari, H. V., \& Suswanto, H. (2017). Pengembangan Media Pembelajaran Berbasis Web Untuk Mengukur Hasil Belajar Siswa Pada Mata Pelajaran Komputer Jaringan Dasar Program Keahlian Teknik Komputer Dan 
Jaringan. Jurnal Pendidikan: Teori, Penelitian, Dan Pengembangan, 2(7), 1008-1016. https://doi.org/10.17977/jptpp.v2i7.9734

Setyaningsih, S., Rusijono, R., \& Wahyudi, A. (2020). Pengaruh Penggunaan Media Pembelajaran Interaktif Berbasis Articulate Storyline Terhadap Motivasi Belajar dan Hasil Belajar Siswa Pada Materi Kerajaan Hindu Budha di Indonesia. Didaktis: Jurnal Pendidikan Dan Ilmu Pengetahuan, 20(2), 144-156. https://doi.org/10.30651/didaktis.v20i2.4772

Sofyan, M. A. H., Muladi, \& Sugandi, R. M. (2018). Faktor-Faktor yang Memengaruhi Keterlaksanaan Unit Produksi SMK pada Program Studi Keahlian Teknik Komputer dan Informatika di Kota Malang. Jurnal Pendidikan: Teori, Penelitian, Dan Pengembangan, 3(5), 552-557. https://doi.org/10.17977/jptpp.v3i5.10980

Sumarni, W., Wardani, S., \& Gupitasari, D. N. (2016). Project Based Learning (PBL) To Improve Psychomotoric Skills : A Classroom Action Research. Jurnal Pendidikan IPA Indonesia, 5(2), 157-163. https://doi.org/10.15294/jpii.v5i2.4402

Sutarno, E., \& Mukhidin. (2013). Pengembangan Model Pembelajaran Berbasis Multimedia Interaktif Pengukuran Untuk Meningkatkan Hasil Dan Kemandirian Belajar Siswa Smp Di Kota Bandung. Jurnal Pendidikan Teknologi Dan Kejuruan, 21(3), 203-218. https://doi.org/10.21831/jptk.v21i3.3258

Ulfah, D. M., \& Soenarto, S. (2017). Pengaruh penggunaan media video dan gambar terhadap keterampilan menulis kelas V. Jurnal Prima Edukasia, 5(1), 22-34. https://doi.org/10.21831/jpe.v5i1.7693

Wajdi, F. (2017). Implementasi Project Based Learning (PBL) Dan Penilaian Autentik Dalam Pembelajaran Drama Indonesia. Jurnal Pendidikan Bahasa Dan Sastra, 17(1), 81-97. https://doi.org/10.17509/bs_jpbsp.v17i1.6960

Yuniarni, D., Sari, R. P., \& Atiq, A. (2020). Pengembangan Multimedia Interaktif Video Senam Animasi Berbasis Budaya Khas Kalimantan Barat. Jurnal Obsesi : Jurnal Pendidikan Anak Usia Dini, 4(1), 290. https://doi.org/10.31004/obsesi.v4i1.331 